\title{
PURA Gene
}

National Cancer Institute

\section{Source}

National Cancer Institute. PURA Gene. NCI Thesaurus. Code C28632.

This gene plays a regulatory role in DNA replication and transcription. 